\title{
THE IMPLICATIONS OF CULTURE SHOCK FOR HEALTH EDUCATORS: REFLECTIONS WITH BARER-STEIN
}

\author{
ML ARTHUR
}

\begin{abstract}
Culture shock is an intensely personal universal human experience that may emerge in any cross cultural social encounter. Therefore, it may be deduced that culture shock is an experience that may occur in all spheres of life in which individuals are confronted by world views and life styles that differ from their own whether in terms of health, education or occupation amongst others. It is a situation that calls for adaptation or adjustment on the part of the individual. This arricle explores the relationship between culture shock and culture adaptation as an aspect of learning which has been developed by Thelma Barer-Stein. Stress is laid on the role of the individual, as health educator, and the choices must make if he/she is to gain an understanding of the community in which he/she serves and to attribute new meanings to the situation by which helshe is confronted.
\end{abstract}

\section{OPSOMMING}

Kultuurskok is ' $n$ intense persoonlike universiële menslike ondervinding wat in enige kruis-kulturele ontmoeting mag voorkom. Daarom kan dit afgelei word dat kultuurskok 'n ondervinding is wat op alle tereine van die lewe kan voorkom waar indiwiduë die verskriklende wêreldebeskouinge en lewenswyse van ander mense teëkom: of dit te doene het met gesondheid, opvoeding en beroep onder andere. Dit is ' $n$ situasie wat verandering of a anpassing benodig. Hierdie artikel ondersoek die verwantskap tussen kultuurskok en kulturele aanpassing as "n deel van die leerproses soos deur Thelma Barer-Stein voorgelê is. Klem word op die indiwidu as gesondheidsvoorligter gelê sowel as op die keuses wat hy/sy moet maak ten einde ' $n$ begrip van die gemeenskap wat hy/sy dien te vekry en om nuwe betekenisse aan die situasie waardeur hy gekonfonteer word toe te dig

\section{INTRODUCTION}

It may be stated that educators, by and large. internalise and reflect prevailing social values towards cultural sub-groups within society and that these values strongly influence the educational outcomes of leamers (Frazier, 1977:13). In turn, every learner brings a unique cultural identity to the oducational milieu. Every educational and, indeed, social situation is a coming together not only of expectations concerning social roles, but also of cultural and personal identity in which notions of self-concept and self-identity play an integral role (Arthur, 1995: 306).

According to Lambert (1989: 273-274), to a large extent psychological comfort is related directly to the perception of a threat to one's 'self' the core of who one feels one is. Self-concept acts as the centre of one's phenomenological world in terms of which all external things are measured and judged. When an individual perceives a situation as hostile or a threat to an aspect of the self-image, defences are raised which become barriers between the self and the perceived threat. In a learning situation in which participants represent a variety of cultures, the potential for psychological discomfort is high. Defence mechanisms therefore may come to the fore in the behaviour of both health educators and their clients.

Parties to cross cultural health education encounters may experience each other at different levels of their respective perceptual fields in terms of 'self. Educators and learners are prepared, albeit in different ways and to varying degrees, to defend that perception. In multicultural societies, clearly identifiable racial and ethric groups as well as the lower classes, females and rural populations will generally maintain a high degree of social distance when they meet They will probably also perceive each other as representatives of 'we-them' configurations, at least, initially (adapted from Christensen, 1985: 69-71)
Every social situation is a coming together, not only of self-concept, self-identity and social roles, but also of shared realities: that which constitutes the intersubjective structure of consciousness.

What is taken for granted by the native is problematic for the stranger. In a familiar world, people live through the day by responding to daily routine without question or reflection. To strangers, however, every situation is new and is therefore experienced as a crisis" (Parillo, in: Gudykunst and Kim, 1984:221).

When people meet who have been socialised within groups with different objectives, but more particularly, subjective cultural characteristics, a cross cultural interaction occurs. The unintentional conflict that emerges as a result of a misunderstanding or the misreading of the cultural cues within the cross cultural encounter is usually experienced as some form of 'culture shock' by both educators and learners alike (Arthur, 1995: 310-311)

\section{CULTURE SHOCK}

The concept of 'culture shock', as introduced by Oberg (1958), traditionally has been used in regards to people belonging to a particular cultural or sub-cultural grouping who settle, either temporarily or permanently, amongst those whose cultural affiliations are different from their own. However, in a world characterised by increasing globalism, the notion has been transferred into the arena of business management in international corporate conglomerations. Barer-Stein (1987 (a); 1987 (b); 1988), has translated the theme into a theory of culture adaptation as an aspect of learning. This is the sense in which the reality of culture shock plays an important role in the success attained by health educators when working with groups whose cultural frame of reference is different from their own.

'Culture shock' is the term used to describe anxiety stemming from a person losing his sense of "how' and 'when' to do the right thing and the ensuing process of adjustment. Initially, the situation involves a non-specific state of uncertainty in which an individual does not know what others expect of him or what he can expect of others in respect of behavioural, psychological, emotional, or 
cognitive responses. The most frequently quoted indicators of culture shock include an absence of familiar cues about how to behave; a sense of helplessness in the new setting; a reinterpretation of familiar values about what is good; an emotional disorientation ranging from anxiety to uncontrollable rage; a feeling that the discomfort will never disappear and a nostalgic idealisation of how things were. In any radically new situation, including health education in the cross cultural encounter, the cultural context is changed in unexpected ways that involve adjustments in respect of social roles and self-identity which result in culture shock (Pedersen, 1994:192).

According to Adler (Pedersen, 1994:192), the culture shock experience is classified into five stages. The first stage of initial contact has been called the 'honeymoon' stage because people initially are enraptured and intrigued by the intercultural experience. The second stage commences when people become frustrated by their inability to interpret the situation appropriately due to a 'disintegration of that which is familiar'. Difference intrudes in a manner which cannot be ignored. The person experiences loneliness, depression, withdrawal and self-blame. Highly ethnocentric reactions may emerge and a high probability of conflict occurs as the third phase begins. Self-blame may turn to hostility, rejection and attacks against the new setting. Trifonovitch (Barer-Stein, 1988: 77-78; Cushner, 1989: 320) combines the second and third stages as described and aptly labels them the 'hostility phase' during which fear, dislike and distrust are commonly experienced emotions (Rothenburger, 1990: 1352). This stage is very volatile as 'reintegration of new cues' takes place. Things are getting better. but not fast enough. People begin to understand the subjective culture of those with whom they work and the way in which things are perceived and accomplished in the new environment. The fourth stage of 'developing a new identity' begins when both differences and similarities are acknowledged. The individual becomes more self-assured as he learns to function in accordance with the new conditions, accepts the strengths and weakness of his old and the new system, adopts some of the local values and becomes integrated within the new social network. This is the phase in which acculturation may be perceived to have set in. The fifth stage ideally leads towards a multi- or bicultural identity. In essence, a stable state of mind is reached ranging from a preference for what has gone before, true bicultural adaptation in which the present is on a par with the past or total conversion to the new environment (Cushner, 1989:320; Hofstede, 1991:209-210; Pedersen, 1994: 192-193).

Pedersen (1994: 193) suggests that recent research on culture shock demonstrates that while the process may be painful, it is not necessarily a negative experience for it results in new insights and positive human growth. Conversely, when intergroup contact fails, the end result frequently includes exclusionary behaviour such as biased evaluations, denigration and disparagement of others. blaming the victim or displacement of the blame for one's actions, self-righteous comparisons justifying retaliations, dehumanisation of the individual, double standards and psychological distancing among others. Any one of these responses on the part of the health educator, singly or in combination, negatively influences the outcome of health education programmes in cross cultural encounters.

Barer-Stein (1988:89), having developed a theory that incorporates notions of culture adaptation and culture shock as aspects of a process of learning, hypothesized that it may be less important for educators to be familiar with the countless details of custom, values, language, behaviour et cetera, than it is for them to understand their own learning as a process.

\section{EXPERIENCING THE UNFAMILIAR: CULTURE ADAPTATION AS AN ASPECT OF THE PROCESS OF LEARNING.}

If enculturation is the outcome of the acquisition of new knowledge and skills, then it may be posited that enculturation is the first step towards acculturation or the ongoing phenomenon of change that occurs when people with different world views come into continuous first hand contact with one another. The act of learning itself implies change (Arthur 1995: 321-322) and the education encounter provides an environment where educators and learners should assimilate some of the views, perceptions and ethos of one another during the course of interaction (Banks \& Lynch, 1986: 22-23).

Existing circumstances and cultural content determine what is accepted and thus learned or what is rejected and, therefore, not learned. If one accepts the truism that people do not learn what is already known, but learn in varying degrees what is not known, it may be concluded that learning is an ongoing "... sequential process of experiencing that which is different or unfamiliar" (Barer-Stein, 1987(a):89). The question may now be posed as to whether a relationship exists between learning, adaptation to culture difference and culture shock. If culture represents the many ways in which people group together, constitute, understand and live their daily lives while at the same time transmitting their way of life to others, then cultural adaptation in cross cultural encounters must involve learning in the form of some sequence of modification or adjustment to a different mode of daily living. A connection between learning and attainment of cultural understanding is hereby established. Culture shock, in these terms, may be viewed ".... as a synonym for coming face to face with the unfamiliar" (Barer-Stein, 1988:88): an experience which may occur in any sphere of life whether in terms of health, occupation or education amongst others.
In developing a model of the process of experiencing the unfamiliar, Barer-Stein (1987(a): 91-92, 94) draws on her conceptualisation of 'Surface' and 'Submerged Knowledge'. The former represents knowledge of which a person is fully aware and the latter, the more obscure levels of knowledge that require effort to recapture. Intrinsic to the approach is an acknowledgment that human consciousness, however fleeting, is an awareness of being faced with that which is unfamiliar or different. The experience is accompanied by a deliberate effort by the individual to exhume, analyse and interpret or reflect on the event. It is an attempt to force aside a natural reluctance to think about that which is unfamiliar and potentially disturbing in order to realise new possibilities and new meanings. As a result of the new understandings derived from in-depth thought or reflection, people are able to reconstruct their current knowledge and activities so that their new insights can be acted upon. In other words, leaming takes place in the form of accommodating to the unfamiliar.

The phenomenologically based model comprises five phases, each of which is associated with essential themes or characteristic behaviours that permeate the entire process with varying degrees of intensity. At each level, reflective pause occurs during which a decision is made whether to move forward towards further understanding or not. At least three sets of interpretive cognitive activities are involved, namely:

\section{- a collecting of information;}

- a questioning of that which is collected and

- a comparison with previous knowledge;

The themes are experienced throughout, either cyclically or on a sequentially regressive or progressive basis. Each phase is entered into voluntarily as a matter of individual choice The possibility of remaining in a phase or essential theme exists (Barer-Stein, 1987(a) 94); 1987(b):29-30; 1988:81-81). Each phase is linked to the individual's personal experience of cultural difference and his/her response to such differences.

The initial phase of the model, labelled Being A ware, denotes access to the unfamiliar. The individual must "... be aware of something in order to distinguish it from anything else" (Barer-Stein, (1987(a):95; 1987(b):30). The three themes or behaviours within this phase represent

- an awareness of the interest itself

- curiosity in the sense of a desire or need to know and

- seduction in the form of an inducement or incentive to do something about the situation 
The second phase of Observing suggests an attentiveness to that which is observed. Brevity and superficiality are characteristics of the reflective pause at this stage. There is no real focus, commitment or responsibility to act. The individual is merely a spectator to that of which he has become aware and now observes. Should attentiveness intensify and focus on a specific interest, the theme of spectator progresses to that of sightseer (Barer-Stein, 1997(a):95-96, 102; 1987(b):30-31; 1988:81).

The third phase of Acting, more appropriately called Acting in the Scene, depicts a movement closer to the object of interest by the individual, from audience to participant. The associated theme or behaviour labelled witness-appraiser indicates an intensification of reflective pause as the individual repeatedly delves deeper into his accumulated and increasing knowledge of the event and of self. Activity melts into that of cultural-missionary or behaviour characterised by a perception that the world is divided into those who have certain collections of knowledge and those who do not. The perception embodies a conviction that one's own culture is correct and is accompanied by a concomitant zeal to do something for those perceived as less fortunate in the form of sharing (perhaps imposing) the benefits of one's own culture on them. The dichotomy between cultures becomes so complete that individual differentiations blur as other people are viewed as homogenous groupings. Stereotyping occurs. The “... judgemental sweeping up of other individuals... into one indistinguishable mass..." (Barer-Stein, 1987(a):97; 1987(b):32) has been labelled cluster-judgement and depicts the 'we-they' dichotomy. Since neither group in this dichotomy is able to comprehend the complexity or reality of each other's culture, cluster-judgement becomes apparent on both sides. Living the life of is the last essential behavioural theme of this phase and represents an ultimate expression of professed familiarity with an unfamiliar situation. It involves an over simplification of the ease with which a person is able to fit into the life-style of another group (Barer-Stein, 1987(a):96-98; 1987(b):31-33; 1988:81).

Confronting, or the fourth phase, is commonly taken to imply impending conflict, but carries the implication of coming face to face with something not previously recognised. The complexity of the life-style of the other group now becomes increasingly apparent. A shift in behaviour occurs as the unfamiliar within the familiar is disclosed, either as an aspect of daily life or from within the self. Security is undermined when the familiar ceases to yield to meaning when reflective pause is applied. The perception that familiar practices no longer work increases and solidifies. As always, the individual has a choice. He may choose to be passive and ignore the confrontation and allow it to pass in a way that denies the capacity for transcending what is learned, thereby inhibiting forward movement. Alternatively, he may choose to engage in conflict utilising the various mechanisms for conflict resolution to disprove the differing reality or he may withdraw into himself or his past familiar world to escape the source of his anxiety. The possibility of a continued Awareness of Interest always exists, in which case the individual transcends or rises above his immediate situation and expands his present reality through the discovery of new meanings and greater understanding (Barer-Stein, 1987(a):98-99; 1987(b):35-38; 1988:82-83).

The final phase is that of Involvement. It represents the reality of experiencing the unfamiliar in such a way that the object or subject that was different now finds an integral place of importance as part of the personality of the individual together with all the other personally relevant meanings that make up his/her daily life. Inherent in the final phase of Involvement is a movement towards a phenomenon that occurs when a particular interest becomes so deeply entrenched within the personality that it becomes internalised and an inextricable part of the self. It becomes one with the daily life of the individual.

Barer-Stein's approach to culture adaptation places emphasis on the individual's experience and his response to that experience as opposed to culture per se or group relationships. It is an approach that is of direct relevance to the work of health educators when working with groups of people whose world view is different from their own whether in respect of health related matters, social roles and role expectations, or patterns of communication.

\section{IMPLICATIONS FOR HEALTH EDUCATORS}

Education or cultural adaptation cannot be said to have taken place as long as learning (as an aspect of understanding that can be acted upon meaningfully) dwells in any place outside of the self. Learning only becomes uniquely personal and part of the self when it is used in some way through an act of involvement. In other words, the onus is on health educators to think deeply or reflect on that which is different or unfamiliar about the culture of the community in which they work.

Health educators need to become consciously aware of the fact that they may be experiencing culture shock in varying degrees in their encounters with others whether in terms of ethnicity, social class, gender or rural-urban distribution. Culture shock may manifest in a variety of responses ranging from surprise that people cannot see the benefits of what is being offered to outrage that communities reject what is perceived as being the only logical effective course of action.

Barer-Stein's approach offers a means for health educators to gain a conscious understanding of the unfamiliar through acts of reflection in order to guide communities to learn more effectively about health related matters. In this sense, the cultural adaptations required are related to the occupational role of the health educator and not necessarily with a view to becoming integrated within the community itself.

The first two phases in Barer-Stein's model are familiar to all health educators - at least in respect of the objective culture. All are A ware of unfamiliar beliefs and practices and are compelled to be interested in these features as they impact directly on their field of work. Curiosity is generally present in so far as prior training has stressed the need to identify differences with a view to doing something about them. The incentive, goal or seduction element has been built into formal planning sessions. Observing is another built-in factor of health education training. For many, the commitment remains at the level of spectator or sightseer in which differences in objective behaviour are noted with a view to changing those perceived to be detrimental to health. At this stage, health educators often are stimulated by the challenges posed by health education in the cross cultural encounter but all too frequentiy, the subjective rationale underlying the beliefs and practices of the community are ignored. Frequently, there is no awareness of the subjective aspects of culture nor of the fact that many variables which directly affect the outcome of educational programmes, are not subject to external observation. Failure to reflect deeply on difference as observed and to concentrate purely on objective observations results in previously mentioned behaviours such as biased evaluations, stereotyping, projection of failure onto clients and the community and mistrust as well as non-realisation of the goals of health education and health promotion.

It is impossible for health educators not to Act in the Scene for they are active participants in all educational events. Questions arise concerning the nature of the participation.

- Is the approach based on direct advice stemming from professional health related knowledge and objective observed difference? If the answer is in the affirmative then health educators cannot be said to have progressed from the second phase of Observing and the end result of their efforts is likely to be almost inevitable failure.

- If a decision is made to move forward in an attempt to understand the community through acts of analysis and interpretation. what are the potential outcomes of such reflection? So often, the behaviour of the educator, represented by the label witness-appraiser, gives rise to the activities of the cultural missionary. Such an approach culminates in a tendency towards imposing personal, professional and cultural practices on others. This action results in cluster-judgement and a reinforcement of the 'we-they' dichotomy in which dislike and distrust become 
manifest. Further progress is unlikely to take place without client-community participation in order to establish the subjective experience of health related matters by both individuals and groups within the community. In this connection, individuals should not be treated in isolation from their reference groups (Dovey \& Mjingwana, 1985:82) for it is a truism to state that psychological, social and physical problems are usually 'group' and seldom 'individual' problems. Shared subjective experience is essential in providing health educators with the necessary baseline information on which to ponder and reflect

- The question 'where to now?" becomes relevant. At this stage, health educators may reach the stage of an oversimplification of their understanding of the life-style and world view of their clientele as outlined in Barer-Stein's essential theme of living the life.

In order to promote movement towards further understanding, the notion of community participation needs to be extended to that of participative learning where learners are called upon to contribute their wide range of quantitative and qualitative experience to the educative event. It is a process in which the reservoir of knowledge and experience of clients and educators are integrated. It is also a process during which it is recognised that the health needs as perceived by professionals may not coincide with those of the community itself. Needs are not present unproblematically in people's lives, but proceed from their interests and goals based on value judgements (Alexander, 1987:137) which evolve from differing socio-economic, cultural and political contexts. It also may be assumed that any group coming together for health education has an unwritten agenda about what they wish to know (Strechlow, 1983:41). In these terms, the decisions and choices made by the community may not be those favoured by health educators. The stage is set for the re-emergence of ethnocentric reactions and mechanisms for conflict resolution on the part of heath educators and, dependent on their response, a resumption of the 'we-they' dichotomy.

On Confronting the realisation of unexpected educational outcomes, health educators are again faced by the unfamiliar. Insecurity is generated in terms of what has or, more realistically, what has not been accomplished. Preconceived goals have not been met and predetermined familiar practices no longer work in terms of desired outcomes. Once again the cultural context has changed in unexpected ways that involve an adjustment in respect of both social and educational roles and self-identity. Should health educators ignore the confrontational issues inherent in the situation by

- withdrawing into themselves,
- retreating into their past familiar world or

- actively engaging an attempt to disprove the opposing realities,

forward movement in understanding the community will be inhibited and successful health education outcomes threatened. Conversely, it is possible for an A wareness of Interest to continue once the undeniable existence of multiple life-world realities is recognised.

Health educators who continue to reflect on and question their own life-world perspectives reduce the likelihood that they will impose preconceived, inappropriate personal cognitions onto the meaning structures of the different orders of reality experienced by learners (Collins, 1984:184).

Involvement entails an acknowledgement that both similarities and differences co-exis within and across cultures. The unfamiliar is experienced in such a way that health educators need to move beyond a pre-occupation with self to understand and confront the issue of how their personal prejudices and prior understandings influence the outcome of any cross cultural encounter. Focus is brought to bear on building mutual understanding rather than concentrating on specific areas of overt cultural difference (Broome, 1991:245-246). In the context of health education, the educator acquires a readiness to suspend taken-for-granted norms in favour of a critical stance towards the everyday experiences of others (Collins, 1984:180-181) as integral part of the self.

As the health educator begins to place emphasis on the experience of cultural difference as opposed to cultural difference per se, the potential for leaming that which is unfamiliar is increased. Deeper insights into the reality of the cross cultural health education encounter may be characterised by the emergence of unique norms and values which may not have existed previously. "A shift into a different behaviour than was previously experienced." (Barer-Stein, 1988:81) or enculturation takes place.

Acculturation in health education practice may be perceived to have set in once the health educator moves away from conventional educational methods which entrench the educator as expert, to those methods founded on placing education within the context in which the cross cultural encounter takes place. By so doing, educators and learners are able to explore the conditions that constitute the structure of their respective life-worlds and come to some understanding of the variables affecting these worlds in order to plan for and take purposeful action to bring about desired change in health related matters with the community. In exploring options for change, the cognitive map of health educators can be extended and limitations in the vision of leamers can be reversed (Mitchell, 1991:19) in order to realise the aims of health education and health promotion

\section{CONCLUSION}

"Health education is an essentially practical activity rooted within educational practice" (French, 1990:9) in which interpersonal and intergroup relationships are an integral part: From the preceding discourse, it may be accepted that in order to develop cross cultural understanding, educators must be motivated to put the necessary effort into working through differences, demonstrate sufficient commitment to the encounter to overcome potential areas of breakdown, be willing and able to explore and negotiate alternative meanings for ideas and situations and be willing to participate in mutual creative exploration in a search for the development of a 'third culture' (Broome, 1991:246-247). The concept of third culture entails a focus centred on the co-operative creation of a shared reality pertaining to health related matters between health educators and clients as opposed to attempts to understand individuals and communities as separate objective cultural entities (Broome, 1991:247).

The initiative for the building of shared meaning between themselves and the community they serve lies in the hands of health educators. Barer-Stein's (1988) approach towards "Experiencing the Unfamiliar: Culture Adaptation and Culture Shock as Aspects of a Process of Leaming" provides the means whereby health educators, by an act of intent, can move beyond a focus on specific areas of overt cultural differences and preoccupation with self to an understanding and confrontation as to how their personal prejudices and prior understandings influence the outcome of health education in cross cultural encounters.

\section{REFERENCES}

Alexander, D.J., (1987): Rural Development Educational Needs and Resources. Studies in the Education of Adults. 19,(2), 137-144.

Arthur, M.L. (1995): Health Education in Cross Cultural Encounters: An Agogical Perspective. Unpublished D.Ed. Thesis. Pretoria: Unisa.

Banks, J.A. \& Lynch, J (Eds.) (1986): Multicultural Education in Westem Societies. London: Holt, Rinehart \& Winston.

Barer-Stein, T. (1987a): Leaming as a Process of Experiencing the Unfamiliar. Studies in the Education of Adults. 19, 87-108.

Barer-Stein, T. (1987b): On the meaning of Learning: Reflections with Dewey. The Canadian Journal of Adult Education 1,(I). 25-50.

Barer-Stein, T. (1988): Experiencing the Unfamiliar: Culture Adaptation and Culture Shock As Aspects of a Process of Learning Canadian Ethics Studies 20(2), 71-91. 
Broome, B J. (1991): Building Shared Meaning. Implications of a Relational Approach to Empathy for Teaching Intercultura Communication. Communication Education 40(3), 235-249.

Christensen, C.P. (1985): A Perceptual Approach to Cross Cultural Counselling. Canadian Counsellor. 19(2), 63-81.

Collins, M. (1984): Phenomenological Perspectives: Some Implications for Adult Education. Merriam, S.B. (ed.). Selected Writings on Philosophy and Adult Education. Malabar: Robert E. Kriegler.

Cushner, K. (1989): Assessing the Impact of a Culture-General Assimilator. International Journal of Intercultural Relations. 13(2), $125-146$.

Dovey, K. \& Mijngwana, R. (1985): Psychology, Rehgion and Healing: The 'Amagquira' in Traditional Xhosa Society. Theoria. 64, 77-83.

Frazier, L. (1977): The Multicultural Facet of Education. Journal of Research and Development in Education. 11(1), 10-16.
French, J. (1990): Boundaries and Horizons, the Role of Health Education within Health Promotion. Health Education Journal. 49(1), 7-9.

Gudykunst, W.B. \& Kim, Y.Y. (1984): Communicating with Strangers: An Approach to Intercultural Communication. Reading: Addison-Welsley.

Hofstede, G. (1991): Cultures and Organizations: Software of the Mind. London: McGraw-Hill.

Lambert, J.W. (1989): Accepting Others Values in the Classroom: An Important Difference. Clearing House. 62(6), 273-274.

Mitchell, S. (1991): There is More than One Way to Play the Multicultural Game. Multicultural Education Joumal. 9(1), 12-20.

Oberg, M.K. (1958): Culture Shock and the Problem of Adjustment to New Cultural Environments. Washington D.C.: V.S. State Department.

Pedersen, P. (1994): Culture-Centered Change: A Three Staged Educational Strategy. Van der
Walt, A. (ed.). The Principles of Multicultural Education. Vanderbijlpark: Vaal Triangle Technikon.

Rothenburger, R.L. (1990): Transcultural Nursing: Overcoming Obstacles to Effective Communication.

Joumal.51(5),1349-1363.

Strechlow, MS. (1983): Education for Health London: Harper \& Rowe.

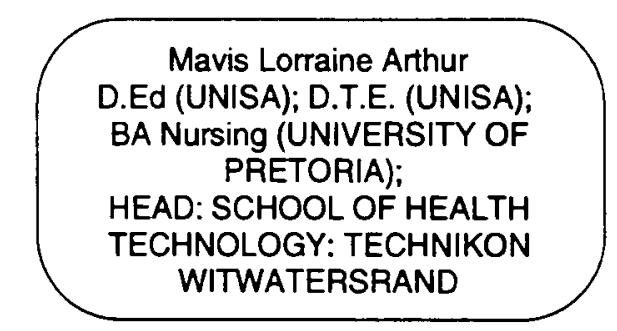

